\title{
Modelling Growth Kinetics of Klebsiella sp. FIRD 2 on TBT-Resistant Containing Lead
}

\section{${ }^{1}$ ABDUSSAMAD, ABUBAKAR; ${ }^{2}$ ABDULLAHI, MUHAMMAD; ${ }^{3}$ DAYYABU SHEHU; ${ }^{3}$ MURTALA, YA'U; ${ }^{3}$ ABBA, BABANDI; ${ }^{4}$ ABUBAKAR, ST; ${ }^{5}$ HADIZA, IBRAHIM; ${ }^{3}$ USMAN, SUNUSI; ${ }^{6}$ FERDAUS, MOHAMAT-YUSUFF; ${ }^{2 *}$ SALIHU, IBRAHIM}

\author{
${ }^{I}$ Department of Microbiology, Faculty of Science, Bauchi State University, PMB 65, Itas Gadau Bauchi, Nigeria \\ ${ }^{2}$ Center For Biotechnology Research, Bayero University, PMB 3011 Kano, Nigeria \\ ${ }^{3}$ Department of Biochemistry, Faculty of Basic Medical Science, Bayero University, PMB 3011 Kano, Nigeria \\ ${ }^{4}$ Department of Biochemistry, Faculty of Science, Bauchi State University, PMB 65, Itas Gadau Bauchi, Nigeria \\ ${ }^{5}$ School of Dental Health Technology, Shehu Idirs College of Health Science and Technology P.M.B 1050 Makarfi, Kaduna State, Nigeria \\ ${ }^{6}$ Department of Environmental Sciences, Faculty of Environmental Studies, Universiti Putra Malaysia, 43400 UPM Serdang, Selangor, \\ Malaysia \\ *Corresponding author Email: sibrahim.cbr@buk.edu.ng
}

\begin{abstract}
Tributyltin (TBT) is one of the most toxic substances ever deliberately introduced into the marine environment. The high toxicity of TBT has resulted in a wide range of adverse effects on biological systems ranging from bacteria to mammals and from the molecular to the community level. One of the most deleterious effects of TBT is imposex. The growth kinetics of TBT-Resistant Bacterium containing lead was studied. In this study various lead concentrations ranging from 1 to $100 \mathrm{mg} / \mathrm{dm}^{3}$ were used. Seven kinetic models (Teissier, Monod, Yano, Luong, Aiba, Webb, and Haldane, ) were investigated and the accuracy of the fitted models were evaluated using statistical analysis such as coefficient of determination, adjusted coefficient of determination $\left(R^{2}\right)$ and root mean square (RMSE). Aiba model was fitted to the experimental growth kinetics data and gave a very good fit with an $R^{2}$ of 0.98 and RMSE of 0.0042 respectively. The calculated value for the Aiba constants such as maximal growth rate, half saturation constant and half inhibition constant rate symbolized by $\mu_{\max }, k_{S}$, and $k_{i}$, were $0.038 \mathrm{hr}^{-1}, 0.38 \mathrm{~s} \mathrm{mg} / \mathrm{dm}^{3}$ and $34.38 \mathrm{mg} / \mathrm{dm}^{3}$ respectively. This is the first report of growth kinetics of TBT-Resistant bacterium by Klebsiella sp. FIRD 2 Containing lead. (C) JASEM
\end{abstract}

https://dx.doi.org/10.4314/jasem.v21i6.15

Keywords: Growth Kinetic models, Klebsiella sp. FIRD 2, lead, TBT-resistant bacteria.

Tributyltin (TBT) is one of the most toxic anthropogenic compounds deliberately introduced into the environment. It has been extensively used as additives in antifouling paints, plastics, biocides and wood preservatives (Hoch, 2001). It has been reported that TBT has some harmful effects in both prokaryotic and eukaryotic organisms (AntizarLadislao, 2008). Inhibition of immune system, endocrine disruption in humans (Dubey et al., 2006) and imposex - superimposition of male characters onto gastropods females are some examples of the toxic effect of TBT in eukaryotes (Barroso et al., 2000; Hoch, 2001). Inhibition of amino acids uptake and growth and interference of TBT with the biological membrane is an example in prokaryotes (Cruz et al., 2012; Jude et al., 2004).

Due of its toxicity to marine organisms, the International Maritime Organization (IMO) in 2008 totally contraband the use of TBT as a constituent of antifouling paints. Yet, there are continuing high concentrations in sediments from fresh and marine waters in many places across the globe including the Strait of Johore, Malaysia (Abubakar et al., 2015; Harino et al., 2008; Zulkifli et al., 2010).
A fraction of heavy metals are essential as trace elements or trace metals to all living organisms, but excessive concentrations can cause severe toxic effects to microorganisms such as bacteria, fungi, algae etc (Poli et al., 2009). The existence of heavy metals at the contamination site is a major restrictive factor for bioremediation, as many organisms cannot withstand high concentration of heavy metals thus losing their capacity to degrade the contaminants (Ibrahim et al., 2015a). Although relatively high levels of these elements occur in natural environment, their presence as a contaminant in ecosystems results mainly from anthropogenic activities (Lima e Silva et al., 2012; Trevors et al., 1985).

Some heavy metals such as zinc, copper, nickel, and iron are essential to metabolic reactions and are required as trace elements by the living organisms. Others like lead, cadmium, mercury, and silver have no apparent biological role and are harmful to the organisms, even at very low concentrations (Hughes $\&$ Poole, 1989). The toxic effects of heavy metals on microorganisms are persuaded by a multitude of factors such as organic matter, speciation, concentration of chelating agents, and $\mathrm{pH}$ (Duxbury, 
1986; Nwuche and Ugoji, 2008). The existence of those elements in the environment can result in impacts on ecosystems, with changes in the biomass, diversity of microbial communities and cycling of elements (Lima e Silva et al., 2012; Sobolev and Begonia, 2008). There are a lot of published papers describing the action of heavy metals on microorganisms. As such, there are studies on the effects of toxic metals in the physiology of metal tolerant bacteria, in comparison to those about their inhibitory or deleterious effects on susceptible organisms (Gupta et al.,1992). This paper describes the effect of various lead concentrations on the growth kinetics of TBT-resistant bacterium; Klebsiella sp. FIRD 2.

\section{MATERIALS AND METHOD}

Bacterial strain: Previously, isolated TBT-resistant bacterium from contaminated surface sediment at Kong Kong Laut along Strait of Johor, Malaysia. The bacterium was identified as Klebsiella sp. FIRD2 (Abubakar et al., 2015). The isolate was maintained on slants/plates agar containing Bactor Agar $25 \mathrm{gL}^{-1}$ added to the minimal salt media. The isolate was maintained and sub-cultured every ten days in the Bactor Agar medium.

Chemicals and Media: Tributyltin chloride (TBTCl) 96\%, was purchased from Sigma, Aldrich USA. Other chemicals used are analytical grade that were obtained from recognized chemicals suppliers, Merck (Darmstadt, Germany) and Fisher (Malaysia). The Minimal Salt Media used contained the following (in $\mathrm{g} / \mathrm{L}): 5 \quad \mathrm{NH}_{4} \mathrm{Cl}, \quad 0.01 \quad \mathrm{CaCl}_{2}, \quad 1.0 \quad \mathrm{KH}_{2} \mathrm{PO}_{4}, \quad 0.01$ $\mathrm{FeSO}_{4} .7 \mathrm{H}_{2} \mathrm{O}, 0.2 \mathrm{MgSO}_{4} .7 \mathrm{H}_{2} \mathrm{O}, 5 \mathrm{NaCl}, 5$-yeast extract. In addition to the above compositions, the media contains $1000 \mu \mathrm{g} / \mathrm{L}$ of $\mathrm{TBT}$ and various concentrations of lead. Carbon sources if any added to the medium were sterilised separately and then mixed to the medium under aseptic conditions.

Growth Kinetics Experiments: Batch experiment was carried out using a shake flask in a $250 \mathrm{~mL}$ Erlenmeyer flask containing $50 \mathrm{~mL}$ of the TBT medium was incubated on a rotary shaker at $150 \mathrm{rpm}$ for $48 \mathrm{hr}$ at room temperature. Samples were drawn after every $6 \mathrm{hr}$ and TBT growth containing lead was measured. The initial temperature and $\mathrm{pH}$ of the medium was adjusted to room temperature and neutral $\mathrm{pH}$, which were the environmental temperature and $\mathrm{pH}$. The seed culture was transferred to $25 \mathrm{~mL}$ of TBT liquid media containing various initial lead concentrations ranging from 1 to $100 \mathrm{mg} / \mathrm{dm}^{3}$ in the $250 \mathrm{~mL}$ Erlenmeyer flask. Samples were collected at different time intervals and measured for cell growth (Agarwal et al., 2009; Ahmad et al., 2015; Gokulakrishnan and Gummadi, 2006; Ibrahim et al., 2015b).

Statistical Analysis: To decide whether there is a statistically substantial difference between models with different number of parameters, in terms of the quality of fit, the same experimental data was statistically assessed through various methods such as the root-mean-square error (RMSE), coefficient of determination $\left(R^{2}\right)$ and the adjusted coefficient of determination $\left(R^{2}\right)$ (Halmi et al., 2014).

Mathematical Model: In this study, the kinetic models as listed in Table 1 were used to represent the kinetics of lead. All the kinetic models were fitted to the experimental data by using a curve fitting toolbox available from MATLAB R2012a based on Windows vista (Singh et al., 2008).

The rate of bacterial growth and degradation can be represented as cell production rate. The formula for various kinetics models is as shown in Table 1 where $S, S_{m}, \mu, \mu_{\max }, K_{s}, K_{i}$, and $n$ are the specific substrate concentration $\left(\mathrm{mg} / \mathrm{dm}^{3}\right)$, the above critical substrate concentration above which cell growth of TBTresistant bacterium containing lead completely stops $\left(\mathrm{mg} / \mathrm{dm}^{3}\right)$, cell growth rate $\left(\mathrm{hr}^{-1}\right)$, maximum cell growth rate $\left(\mathrm{hr}^{-1}\right)$, saturation constant or half velocity constant $\left(\mathrm{mg} / \mathrm{dm}^{3}\right)$, inhibition constant $\left(\mathrm{mg} / \mathrm{dm}^{3}\right)$, and the exponent representing the impact of the substrate to $\mu_{\max }$, respectively. For each initial concentration of lead, specific growth rate was calculated based on the linear portion of the growth against time in an exponential phase. The specific growth rate $(\mu)$ in exponential phase was calculated by the following equation:

$\mu=\frac{X_{2}-X_{1}}{t_{2}-t_{1}}$

where $\mathrm{X}_{1}$ and $\mathrm{X}_{2}$ are the cell dry weight obtained at time $\mathrm{t}_{1}$ and $\mathrm{t}_{2}$, respectively. All experiments were conducted in triplicates under identical conditions and all the values were expressed as mean standard deviation (Gokulakrishnan and Gummadi, 2006). 
Table 1: Various kinetic models for effect of substrate on

\begin{tabular}{|c|c|c|}
\hline Author & $\mu$ (Growth rate) & References \\
\hline \multirow[t]{2}{*}{ Monod } & $S$ & (Monod, 1949) \\
\hline & $\mu_{\max } \frac{\overline{K_{S}+S}}{S}$ & \multirow{2}{*}{ (Haldane, 1930) } \\
\hline Haldane & $\mu_{\max } \frac{S}{S+K_{s}+\left(\frac{S^{2}}{K_{i}}\right)}$ & \\
\hline Luong & $\mu_{\max } \frac{S}{K_{S}+S}\left[\left(1-\left(\frac{S}{S_{m}}\right)^{n}\right]\right.$ & (Luong, 1987) \\
\hline Aiba & $\mu_{\max } \frac{S}{K_{S}+S} \exp ^{\left(-S / K_{i}\right)}$ & (Aiba et al., 1968) \\
\hline Teissier & $\mu_{\max }\left(1-\exp \left(-\frac{S}{K_{s}}\right)\right)$ & (Teissier, 1942) \\
\hline Yano & $\mu_{\max S}$ & (Yano et al., 1966) \\
\hline \multirow[t]{2}{*}{ Webb } & $\begin{array}{c}S+K_{S}+\left(\frac{S^{2}}{K_{I}}\right)\left(1+\frac{S}{K}\right) \\
\mu_{\max } S\left(1+\left(\frac{S}{K}\right)\right)\end{array}$ & \multirow[t]{2}{*}{ (Webb, 1963) } \\
\hline & $\overline{K_{S}+S+\left(\frac{S^{2}}{K_{\dot{s}}}\right)}$ & \\
\hline
\end{tabular}

\section{RESULT AND DISCUSSION}

Effect of Initial Concentration on Growth Curve: Figure 1 shows the time course profile of the TBTresistant growth curve of Klebsiella sp. FIRD 2 by the shake flask culture. The culture is able to resist upto $40 \mathrm{mg} / \mathrm{dm}^{3}$ lead in almost $48 \mathrm{hr}$. It was observed that the time taken for the culture to grow in the presence of lead is depended on its initial concentration of the lead. It was found that the bacterial growth decreased with an increase in lead concentration. At a concentration of $1 \mathrm{mg} / \mathrm{dm}^{3}$ the bacterial isolate grows optimally with an $\mathrm{OD}_{600}$ of 1.388 while at a concentration of $100 \mathrm{mg} / \mathrm{dm}^{3}$, it completely inhibits the growth of Klebsiella sp. FIRD 2 as shown in Figure 1

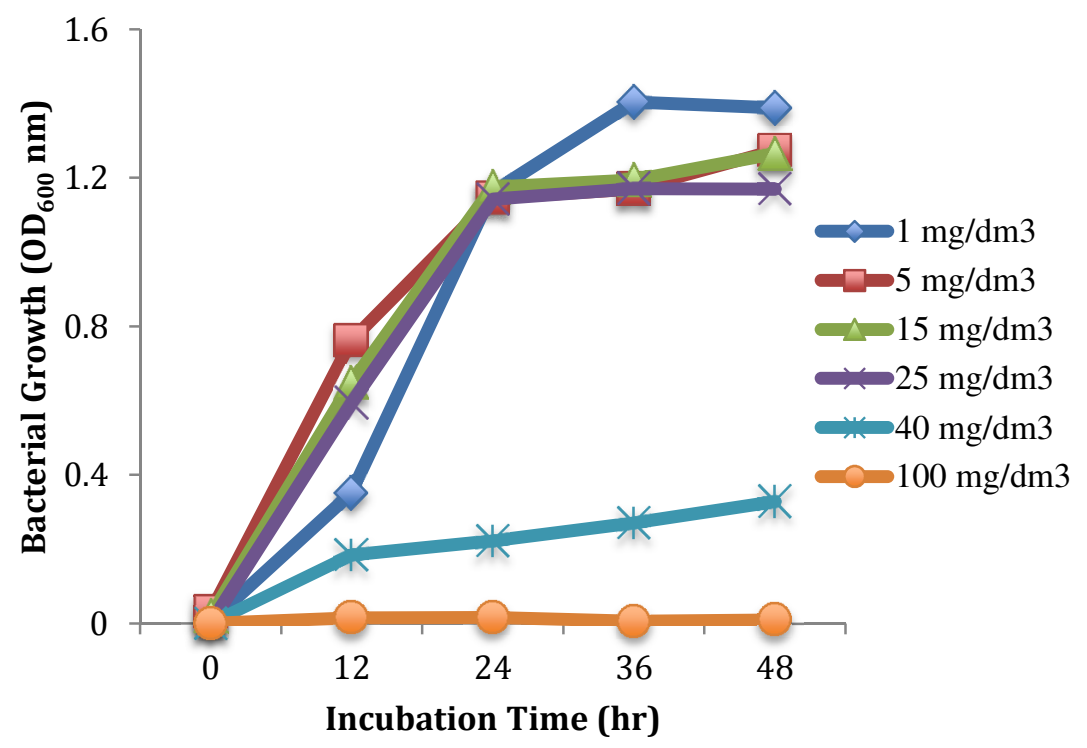

Fig 1: Effect of various lead concentrations on Klebsiella sp. FIRD 2 growth containing TBT. Data represent mean \pm STDEV, $\mathrm{n}=3$. 
Microbial Growth Kinetics: Based on the growth curves of Klebsiella sp. FIRD 2 (Figure 1), the specific growth rate $(\mu)$ for each initial lead concentration $(\mathrm{S})$ was calculated. One of the valuable tool in biotechnology is the relationship between the specific growth rate $(\mu)$ of a population of microorganisms and the substrate concentration (S) which are represented by a set of empirically derived rate laws referred to as theoretical models. These models are nothing but mathematical expressions generated to describe the behavior of a given system (Okpokwasili and Nweke, 2005; Ibrahim et al., 2015b).

The results of the curve fitting are shown in Figure 2.
Models such as Luong and Monod failed to fit the experimental data and were omitted. All of the other models tested gave reasonably good fitting based on software output. The accuracy and statistical analysis of the six kinetic models used showed that the best model was Aiba with the highest value for adjusted $\mathrm{R}^{2}$ and lowest value for RMSE. The $\mathrm{R}^{2}$ and adjusted $\mathrm{R}^{2}$ values were also excellent for Aiba with their values being close to 1.0 as shown in Table 2, which could be attributed based on the models themselves, which are considered more refined from the standpoint of development of these models (Dey and Mukherjee, 2010).

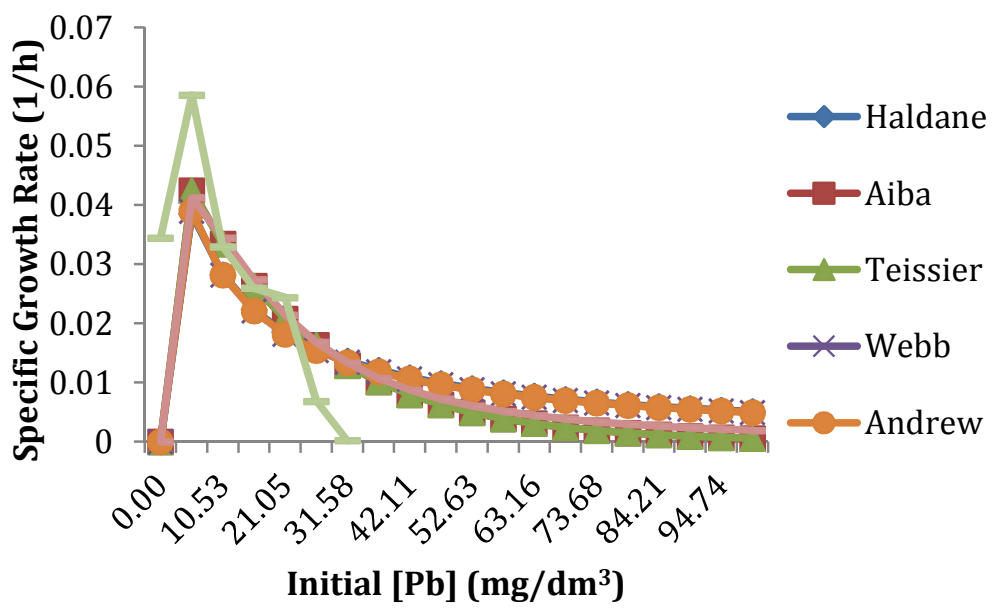

Fig 2: Fitting experimental data with the different kinetics model.

The growth kinetic constant of the batch culture as shown in Table 2 reported the value $\mu_{\max }$ and $K s$ by nonlinear regression method as per Monod. The calculated value for the Aiba constants in this work such as maximal growth rate, half saturation constant and half inhibition constant rate symbolized by $\mu_{\max }$, $k_{S}$, and $k_{i}$, were $0.03759 \mathrm{hr}^{-1}, 0.3748 \mathrm{mg} / \mathrm{dm}^{3}$ and $34.38 \mathrm{mg} / \mathrm{dm}^{3}$, respectively.
The $\mu_{\max }$ value obtained needs to be cautioned, as the value obtained based on curve fitting interpolation is not the true value as the true $\mu_{\max }$ should be where the gradient for the slope is zero (Halmi et al., 2014) and in this case, Aiba value was approximately $0.0424 \mathrm{hr}^{-1}$ at $5.2632 \mathrm{mg} / \mathrm{dm}^{3}$ lead (Figure 2). The constant $\mathrm{n}$ was found to be 1.234, indicating a non-linear correlation between specific growth and the initial substrate concentration.

Table 2: Kinetic Model Parameter

\begin{tabular}{cccccccccc}
\hline Model & $\mu_{\max }\left(\mathrm{hr}^{-1}\right)$ & $\mathrm{K}_{\mathrm{s}}\left(\mathrm{mg} / \mathrm{dm}^{3}\right)$ & $\mathrm{K}_{\mathrm{i}}\left(\mathrm{mg} / \mathrm{dm}^{3}\right)$ & $\mathrm{K}\left(\mathrm{mg} / \mathrm{dm}^{3}\right)$ & $\mathrm{S}_{\mathrm{m}}\left(\mathrm{mg} / \mathrm{dm}^{3}\right)$ & $\mathrm{R}^{2}$ & Adjusted $\mathrm{R}^{2}$ & $\mathrm{RMSE}$ & $\mathrm{n}$ \\
\hline Aiba & 0.038 & 0.38 & 34.38 & & & 0.98 & 0.96 & 0.0042 \\
Webb & 0.079 & 0.47 & 1.017 & 6.03 & & 0.83 & 0.65 & 0.025 \\
Monod & 0.018 & 0.71 & & & & 0.75 & 0.69 & 0.012 \\
Yano & 0.035 & 0.43 & 22.3 & 1.89 & & 0.95 & 0.89 & 0.007 \\
Luong & 0.048 & 0.38 & & & 94.23 & 0.97 & 0.94 & 0.005 & 1.23 \\
Teissier & 1.022 & 8.40 & 9.18 & & & 0.42 & 0.13 & 0.019 \\
Haldane & 0.043 & 0.32 & 16.64 & & & 0.96 & 0.93 & 0.006 \\
\hline
\end{tabular}


In most of the studies concerning substrate inhibition on microbial growth are carried out using toxic substrate such as aromatic hydrocarbons and hence it can be concluded that at high concentration growth rate will be severely affected and the normal use of the monod model will fail (Halmi et al., 2014). Lead currently have no known biological function in bacteria and may disturb the normal functioning of an organism if bioaccumulate (Hynninen, 2010). $\mathrm{Pb}^{2+}$ cause toxicity by interacting with nucleic acids, by binding to essential respiratory proteins (Vallee and Ulmer, 1972), and through oxidative damage by production of reactive oxygen species (Stohs and Bagchi, 1995). $\mathrm{Pb}^{2+}$ enter bacterial cells via transport systems for essential divalent cations, such as $\mathrm{Mn}^{2+}$ (Hynninen, 2010; Tynecka et al., 1981) and $\mathrm{Zn}^{2+}$ (Grass et al., 2002; Laddaga and Silver, 1985).

As described by Wayman and Tseng, (1976), there were other models for describing substrate kinetics inhibition established during this period, such as the discontinuous models. Discontinuous model was developed due to the fact that in the previous models developed (Webb, Andrews And Noack, and Haldane), only inhibitory effect on microbial growth were described but could not explain or adequately model for certain situations where the growth rate completely ceased or becoming zero at very high substrate concentration. While Luong in 1987 developed a continuous type of the model above that has popular support due to its close agreement to experimental data in some cases (Halmi et al., 2014; Hamitouche et al., 2012; Nickzad et al., 2012; Othman et al., 2013). A central attraction of the Luong model is its ability to successfully predict the value of $S_{m}$, the maximum substrate concentration above which growth is completely inhibited.

Conclusion: The kinetics of Klebsiella sp. FIRD 2 on TBT-Resistant containing lead was studied under aerobic condition. The kinetic models were fitted to the experimental data and kinetic parameters were determined. It was observed that the best model that fit the present study is Aiba model having the highest $\mathrm{R}^{2}$ value of 0.98 and lowest RMSE value of 0.0042 and predicting reasonable kinetic coefficient values. Amongst all the kinetic models, Teissier gave a poor $\mathrm{R}^{2}$ of 0.42 .

\section{REFERENCE}

Abubakar, A; Mustafa, MB; Wan Johari, WL; Zahmir, S; Ismail, A; Mohamat-yusuff, FB
(2015). Klebsiella sp . FIRD 2 , a TBT-resistant bacterium isolated from contaminated surface sediment along Strait of Johor Malaysia. Mar. Pollut. Bull, 101, 280-283.

Agarwal, R; Mahanty, B; Dasu, VV (2009). Modeling Growth of Cellulomonas cellulans NRRL B 4567 under Substrate Inhibition During Cellulase Production. Chem. Biochem. Eng. Q. 23(2), 213-218.

Ahmad, SA; Ibrahim, S; Shukor, MY; Johari, WLWJ; Rahman, NA; Syed, MAS (2015). Biodegradation kinetics of caffeine by Leifsonia sp. strain SIU. J. Chem. Pharm. Sci. 8(2), 312316.

Aiba, S; Shoda, M; Nagalani, M (1968). Kinetics of product inhibition in alcohol fermentation. Biotechnol. Bioeng 10(6), 845-864.

Antizar-Ladislao, B (2008). Environmental levels, toxicity and human exposure to tributyltin (TBT)-contaminated marine environment. A review. Environ. Int 34(2), 292-308.

Barroso, CM; Moreira, MH; Gibbs, PE (2000). Comparison of imposex and intersex development in four prosobranch species for TBT monitoring of a southern European estuarine system (Ria de Aveiro, NW Portugal). Mar. Ecol. Prog. Ser 201, 221-232.

Cruz, A; Oliveira, V; Baptista, I; Almeida, A; Cunha, A; Suzuki, S; Mendo, S (2012). Effect of tributyltin (TBT) in the metabolic activity of TBT- resistant and sensitive estuarine bacteria. Environ Toxicol. 27(1), 11-17.

Dey, S; Mukherjee, S (2010). Performance and kinetic evaluation of phenol biodegradation by mixed microbial culture in a batch reactor. Int. $J$. Water Resour. Environ. Eng. 2(3), 40-49.

Dubey, SK; Tokashiki, T; Suzuki, S (2006). Microarray-mediated transcriptome analysis of the Tributyltin (TBT)-resistant bacterium Pseudomonas aeruginosa $25 \mathrm{~W}$ in presence of TBT. J. Microbiol. 44(2), 200-205.

Duxbury, T (1986). Microbes and heavy metals: an ecological overview. Microbiol. Sci. 3(11), 330333. 
Gibbs, P; Bryan, G (1996). TBT-induced imposex in neogastropod snails: masculinization to mass extinction. In: SJ M (ed) Tributyltin: case study of an environmental contaminant, vol 8 . Cambridge Environmental Chemistry. Cambridge University Press, Cambridge, (pp. 212-236).

Gokulakrishnan, S; Gummadi, SN (2006). Kinetics of cell growth and caffeine utilization by Pseudomonas sp. GSC 1182. Process Biochem. 41(6), 1417-1421.

Grass, G; Wong, MD; Rosen, BP; Smith, RL; Rensing, C (2002). ZupT is a $\mathrm{Zn}(\mathrm{II})$ uptake system in Escherichia coli. J. Bacteriol. 184, 864-6.

Gupta, L. K., Jindal, R., Beri, H. K., \& Chhibber, S. (1992). Virulence of silver-resistant mutant of Klebsiella pneumoniae in burn wound model. Folia Microbiol. 37(4), 245-248.

Haldane, JBS (1930). Enzymes, London, Longmans, Green.

Halmi, MIE; Shukor, MS; Wan Johari, WL; Shukor, MY (2014). Mathematical Modeling of the Growth Kinetics of Bacillus sp. on Tannery Effluent Containing Chromate. J. Environ. Bioremediation Toxicol. 2(1), 6-10.

Hamitouche, AE; Bendjama, Z; Amrane, A; Kaouah, F; Hamane, D (2012). Relevance of the Luong model to describe the biodegradation of phenol by mixed culture in a batch reactor. Ann. Microbiol. 62(2), 581-6.

Harino, H; Arai, T; Ohji, M; Ismail, A; Miyazaki, N (2008). Organotin contaminations in Malaysia. Coast. Mar. 32(1), 96-101.

Hoch, M (2001). Organotin compounds in the environment - an overview. Appl. Geochemistry, 16(16), 719-743.

Hughes, MN; Poole, RK (1989). The functions of metals in micro- organisms. In: Hughes, M.N.; Poole, R.K. (eds). In Metals and microorganisms. Chapman and Hall, London (pp. 1-38).

Hynninen, A (2010). Zinc, cadmium and lead resistance mechanisms in bacteria and their contribution to biosensing.

Ibrahim, S; Muhammad, A; Tanko, AS; Abubakar, A; Ibrahim, H; Shukor, MY; Ahmad, SA (2015a). Studies of Action of Heavy Metals On Caffeine degradation by Immobilised Leifsonia sp. strain SIU. Bayero J. Pure Appl. Sci. 8(2), 138-144.

Ibrahim, S; Shukor, MY; Syed, MA; Wan Johari, WL; Ahmad, SA (2015b). Characterisation and growth kinetics studies of caffeine-degrading bacterium Leifsonia sp. strain SIU. Ann. Microbiol. 1-10.

Jude, F; Arpin, C; Brachet-Castang, C; Capdepuy, M; Caumette, P; Quentin, C (2004). TbtABM, a multidrug efflux pump associated withtributyltin resistance in Pseudomonas stutzeri. FEMS Microbiol. Lett. 232(1), 7-14.

Laddaga, RA; Silver, S (1985). Cadmium uptake in Escherichia coli K-12. J. Bacteriol. 162, 11001105.

Lima e Silva, AA; Ribeiro de Carvalho, MA; Souza, SAL; Dias, PMT; Filho, RGS; Saramago, CS; de M; Hofer, E (2012). Heavy Metal Tolerance (Cr, $\mathrm{Ag}$ And $\mathrm{Hg}$ ) In Bacteria Isolated From Sewage. Brazilian J. Microbiol. 1620-1631.

Luong, JHT (1987). Generalization of Monod kinetics for analysis of growth data with substrate inhibition. Biotechnol. Bioeng. 29(2), 242-248.

Monod, J (1949). The growth of bacterial cultures. Annu. Rev. Microbiol. 3, 371-394.

Nickzad, A; Mogharei, A; Monazzami, A; Jamshidian, H; Vahabzadeh, F (2012). Biodegradation of phenol by Ralstonia eutropha in a Kissiris- immobilized cell bioreactor. Water Environ. Res. 84(8), 626-34.

Nwuche, CO; Ugoji, EO (2008). Effects of heavy metal pollution on the soil microbial activity. Int. J. Environ. Sci. Technol. 5(3), 409-414.

Okpokwasili, GC; Nweke, CO (2005). Microbial growth and substrate utilization kinetics. African J. Biotechnol. 5(4), 305-317. 
Othman, AR; Bakar, NA; Halmi, MIE; Johari, WLW; Ahmad, SA Jirangon, H; Syed, MA; Shukor, MY (2013). Kinetics of molybdenum reduction to molybdenum blue by Bacillus sp. strain A.rzi. Biomed Res. Int. 1-9.

Poli, A; Salerno, A; Laezza, G; Dumontet, S; Nicolaus, B (2009). Heavy metal resistance of some thermophiles: potential use of a-amylase from Anoxybacillus amylolyticus as a microbial enzymatic bioassay. Res. Microbiol. 160(2), 99106.

Singh, KR; Kumar, S; Kumar, S; Kumar, A (2008). Biodegradation kinetic studies for the removal of p-cresol from wastewater using Gliomastix indicus MTCC 3869. Biochem. Eng. J. 40, 293303.

Sobolev, D; Begonia, MF (2008). Effects of heavy metal contamination upon soil microbes: leadinduced changes in general and denitrifying microbial communities as evidenced by molecular markers. Int. J. Environ. Resour. Public Heal. 5(5), 450-456.

Stohs, SJ; Bagchi, D (1995). Oxidative mechanisms in the toxicity of metal-ions. Free Radic. Biol. Med. 18, 321-36.

Teissier, G (1942). Croissance des populations bacte'riennes et quantite'd'aliment disponible (Growth of bacterial populations and the available substrate concentration). Revis. Sci. 80,
209.

Trevors, JT; Oddie, KM; Belliveau, BH (1985). Metal resistance in bacteria. FEMS Microb. Rev. 32(1), 39-54.

Tynecka, Z; Gos, Z; Zajac, J (1981). Reduced cadmium transport determined by a resistance plasmid in Staphylococcus aureus. J. Bacteriol. 147, 305-12.

Vallee, BL; Ulmer, DD (1972). Biochemical effects of mercury, cadmium and lead. Annu. Rev. Biochem. 41, 91-128.

Wayman, M; Tseng, MC (1976). Inhibition threshold substrate concentrations. Biotechnol. Bioeng. 18(3), 383-387.

Webb, JL (1963). "Enzymes and Metabolic Inhibitors.” In Boston: Academic Press.

Yano, T; Nakahara, T; Kamiyama, S; Yamada, K (1966). Kinetic studies on microbial activities in concentrated solutions. I. Effect of excess sugars on oxygen uptake rate of a cell-free respiratory system. Agric. Biol. Chem 30, 42-48.

Zulkifli, SZ; Ismail, A; Mohamat-yusuff, F; Arai, T; Miyazaki, N (2010). Johor Strait as a Hotspot for Trace Elements Contamination in Peninsular Malaysia. Bull. Environ. Contam. Toxicol. 84, 568-573. 